\title{
The dynamics of structural changes in the social-role attitudes of students during studies at higher educational institution
}

\author{
Olha Savytska ABDEF \\ The Department of Psychology of Education \\ Kamianets-Podilskyi National Ivan Ohiienko University
}

\begin{abstract}
The purpose of the paper - to present the theoretical considerations and the results of empirical study concerning on the intentional characteristics of professional consciousness (on the example of social-role attitudes of students). The structure, the dynamics of changes in the social-role attitudes of students during studies at higher educational institution in different forms of studies (full-time and part-time) and the influence of the quality of program content transferred during the education process on the shaping of students' professional awareness were also discussed.

The methodology of the research. We used the method of questioning and incomplete sentences in the research. The sample consisted of 94 students of 1 - 5 courses in the following fields: psychology, primary education, mathematics and physics. The study involved 17 part-time students and 77 full-time students. The age of full-time students was from 17 to 22 years old, and the age of part-time students was from 24 to 35 years old. Methods of mathematical statistics are used to evaluate the data.

The results of the research. The data of the empirical research of the students' social-role attitudes show that they have content peculiarities as for the specifics of manifestation at different stages of professional training and on different forms of studies at higher educational institution. Social attitudes regarding the role of "student" and the role of "professional" which have threecomponent structure (cognitive, emotional and behavioural) vary in degree of awareness and completeness, and are ambivalent. This increases their resilience to changes.
\end{abstract}

The discussion. The results of the studies show that the social-role attitudes undergo changes as a result of target influences in the process of professional training of future specialists at higher educational institution. Therefore, the definition of social-role attitudes features will contribute to the development of the effective technologies in the professional training of specialists.

Keywords: personal-professional development, professional consciousness, attitude, social-role attitudes, psychological training.

\section{Streszczenie}

Celem artykułu jest prezentacja rozważań teoretycznych oraz wyników empirycznego badania dynamiki treści świadomości zawodowej studentów (na przykładzie postawy społecznej studentów). Omówiono także strukturę i dynamikę zmian w postrzeganiu pełnionych ról społecznych wśród studentów w trakcie ich nauki na uczelni wyższej na różnych trybach studiów (dzienne, zaoczne) oraz przedstawiono wpływ jakości przekazywanych w trakcie procesu edukacji treści programowych na kształtowanie się świadomości zawodowej studentów.

Metodyka badania. W badaniu wykorzystano metodę zdań niedokończonych. Grupę badaną stanowiło 94 studentów uczęszczających na 1-5 kursów z następujących dziedzin: psychologia, edukacja wczesnoszkolna, matematyka i fizyka. Do opracowania uzyskanych danych wykorzystano metodę statystyki matematycznej.

Wyniki badań. Uzyskane wyniki badania empirycznego postrzeganych ról społecznych studentów wskazują, że wystepujące treści są specyficzne dla różnych etapów kształcenia zawodowego oraz dla różnych form studiów na uczelni wyższej. Postrzeganie społeczne roli „student”, i roli „specjalista”, wskazuje na występowanie trójskładowej struktury (kognitywna, emocjonalna i behawioralna) o różnym stopniu świadomości oraz kompletności, co zwiększa jej odporność na zmiany.

Dyskusja. Wyniki badań świadczą, że postrzeganie ról społecznych zmienia się w wyniku celowo skierowanych oddziaływań w procesie kształcenia zawodowego przyszłych specjalistów na uczelni wyższej. Określenie specyfiki postrzegania ról społecznozawodowych pozwoli na opracowanie skutechnych metod kształcenia zawodowego przyszłych specjalistów.

Słowa kluczowe: rozwój osobowościowo-zawodowy, świadomość zawodowa, postawy, postrzeganie ról społecznych, trening psychologiczny. 


\section{Introduction}

The profession influences the personality and leads to its regular changes. The most significant and the most noticeable changes cause the professions of the "human human" type. The inopportune overcoming of the negative effects of the professional activity of this type causes an increase in professional deformations of the individual and the appearance of occupational illnesses. According to studies by G. M. Meshkov, only $7.6 \%$ of teachers feel relatively healthy, they have a high level of efficiency and high stress resistance. At the same time, 77.3\% of teachers found violations in the emotional sphere, and $96 \%$ of teachers associate them with professional activities, in particular, with a number of psycho-traumatic factors, overstress, etc. [1].

Such multilevel, system-determinated formation as professional consciousness can provide complex processes of mental regulation of the professional activity, professional communication and personality as a subject of labour. The study of the dynamics of structural changes in the socialrole attitudes of students during vocational training is the prerequisite for the development of effective psychological support for the professional development of the specialist's personality. Understanding of the changes in the content characteristics of professional consciousness is necessary for forecasting the specificity of the professionalization of a young specialist and the timely providing psychological assistance in the event of the preconditions for professional deformations.

To understand the specificity of social-role attitudes in the way of protecting professional consciousness concerning full-time and part-time students of different courses and different training fields, the researchers planned and carried out the experimental research based on the following ideas: firstly, the professional consciousness reflects the specificity of the professional training process in the conditions of higher educational institution [2]; secondly, the social attitude has a regulatory effect on the behaviour and professional activity of a specialist [3], and is an attribute, a meaningful component of the professional consciousness [4]; thirdly, the process of different social attitudes formation, changing and strengthening is possible in the study process under the condition of adequate social-psychological influences on the personality [5].

Accordingly, the hypotheses of the study are: 1) the intentional characteristics of the professional consciousness (social-role attitudes) are changing, influenced by forms and duration of study in higher educational institution; 2) social-role attitudes are ambivalent and have threecomponent structure (cognitive, affective and behavioural); 3) the repertoire of evaluative judgments, which represent the behavioural component of students' social-role attitudes expands due to the duration of training, which evidences the development of students' professional consciousness; 4) evaluative judgments, representing the cognitive component of social-role attitudes, reflect the value orientations of students, and this allows to observe the process of professional consciousness formation in the study process at higher educational institution.

\section{Materials and methods}

The sample was formed by random method and involved 94 students enrolled in from one to five courses in the field of psychology (44 students), primary education (17 students), mathematics (17 students) and physics (16 students). Seventeen persons were part-time students and seventy-seven were full-time students. All the parttime students worked on their specialty. The age of full-time students was 17 - 22 years old, and of part-time students, 24 - 35 years old.

The researchers used the method of diagnostic examination by means of the questionnaire 'Students about themselves and about profession' by H. V. Akopov [4].

The questionnaire consisted of five open questions. Three questions were constructed according to the principle of incomplete sentences and envisaged formulating judicious opinions concerning the social roles 'I am a Student', 'I am not a student', 'We are students', the last two - envisaged an assessment of professional activity and were based on the use of predictive reflection mechanisms.

Results. An analysis of 94 respondents' answers allowed to assess the dynamics of structural changes in the social-role attitudes of students and to identify its specificity.

During the survey on the first three questions of the questionnaire, a total of 1,286 evaluative judgments were received (456 of them - on the first question, 441 - on the second, and 389 - on the third one). Some respondents formulated 2-3 evaluative judgments instead of 4-5. All the received judgments were subjected to content analysis. In its implementation it was confirmed that attitude has threecomponent structure (cognitive, emotional and behavioural ones). The evaluative judgments, that form the cognitive component of a social attitude, are associated with the individual value orientations, emotional phenomena, as well as with a program of behaviour or activity that can be verbalized by a person concerning certain conditions and specific questions of the researcher.

The researchers used methods of content-analysis for static processing of the received data, determining the levels and frequency of characteristics in percentage terms. The processing of the results reduced to the registration of evaluative judgments for each structural element of the attitude, to the typification of cognitive component evaluative judgments of the structure of the attitude by their 
relationship to value orientations and to their calculation as a percentage of the total number of students' answers of a particular course / specialty. Estimated judgments (in percent) were added: a) according each course; b) according the structural element of the attitude. Interpretation was built on the quantitative expression: the higher the indicators, the more aware is the social set or its separate components (Table 1.)

The obtained results of the empirical study of socialrole attitudes of students revealed the following (See Tab. 1.):

1. The repertoire of evaluative judgments of each questionnaire separately in the six selections (by course and specialty) in the quantitative measurement does not contain significant differences and varies in the range of 31-44 judgments, with an average of 38 judgments. The analysis of the frequency of evaluative judgments found that from $37.1 \%$ to $65.9 \%$ of judgments occur only once, what suggests a sufficient heterogeneity of verbal representations of social-role attitudes.

2. In the system of evaluative judgments of respondents, the cognitive component of the social attitude is presented the most completely. Students of all courses and forms of education were least inclined to express their own probable behaviour as for the objects/situations, proposed
$41 \%$ of the total number of judgments, whereas in the senior courses it is only $15 \%$.

The description of expected/planned behaviour in the role of student / non-student contains $20-37 \%$ of the evaluative judgments of graduate students versus $12-17 \%$ of the evaluative judgments of freshmen. First-year students feel confident in their status, naturally, they can describe the expected planned behaviour and activity of non-student and student. In the senior courses, the objects and situations that are beyond the educational activity and the role of student cause strong emotions, which would require verbalisation in the situation of the survey. As the answers of respondents for the fourth and fifth questions have shown, the professional activity becomes such an object.

3. The social attitude concerning the role of student is ambivalent. It should be noted that in the describing the role of 'I am a student', there are no negative evaluative judgments, what is explained by the impact of the psychological protection mechanisms of the positive 'selfconcept'. Their insignificant number was recorded in the describing the role of 'we are students' $7.5 \%$ of the total estimation judgments on this question). Such attribution of negative judgments to the group the respondent belongs to, is connected with defining of the psychological boundary

Table 1. The structure indices of social attitudes of students of different courses and training areas (\%)

\begin{tabular}{|c|c|c|c|c|c|c|c|c|c|c|c|c|c|c|c|c|c|c|}
\hline & \multicolumn{3}{|c|}{$\begin{array}{l}1 \text { course } \\
\text { mathematics }\end{array}$} & \multicolumn{3}{|c|}{$\begin{array}{l}1 \text { course } \\
\text { physics }\end{array}$} & \multicolumn{3}{|c|}{$\begin{array}{l}2 \text { course } \\
\text { primary } \\
\text { education }\end{array}$} & \multicolumn{3}{|c|}{$\begin{array}{l}3 \text { course } \\
\text { psychology }\end{array}$} & \multicolumn{3}{|c|}{$\begin{array}{l}4 \text { course } \\
\text { psychology }\end{array}$} & \multicolumn{3}{|c|}{$\begin{array}{l}5 \text { course } \\
\text { psychology }\end{array}$} \\
\hline & 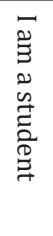 & 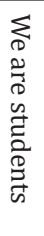 & 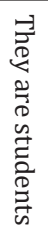 & 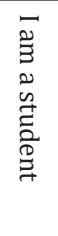 & 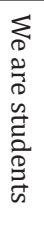 & 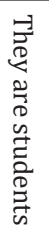 & 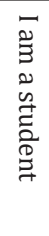 & 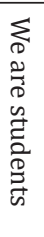 & 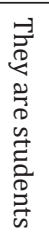 & 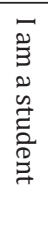 & 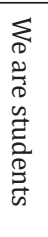 & 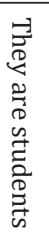 & 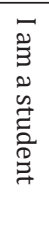 & 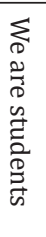 & 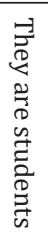 & 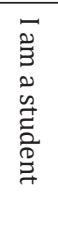 & 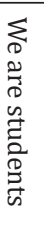 & 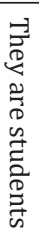 \\
\hline Cognitive & 64 & 56 & 55 & 58 & 67 & 44 & 50 & 62 & 62 & 63 & 52 & 42 & 68 & 62 & 54 & 65 & 75 & 65 \\
\hline Emotional & 24 & 32 & 29 & 25 & 18 & 41 & 30 & 20 & 25 & 9 & 22 & 15 & 11 & 12 & 9 & 14 & 3 & 15 \\
\hline Behavioural & 12 & 12 & 16 & 17 & 15 & 15 & 20 & 18 & 13 & 28 & 26 & 43 & 21 & 26 & 37 & 21 & 22 & 20 \\
\hline
\end{tabular}

for estimation. The duration of students' studies, the level of mastering their educational role of student greatly influences the changes in the emotional component of social attitude. This is evidenced by a decrease in the number of emotionally coloured estimation judgments regarding the proposed objects/situations with the duration of studies in higher educational institution. Thus, in particular, in the 1st-2nd courses, their number is much higher and reaches between the group and own 'self'. In this way, the individual manages to maintain a high self-esteem and positive selfconcept, and to attribute negative judgments to the other members of the group. The highest number of negative evaluative judgments (66.1\%) was found in describing the role of 'They are not students'. This group is 'strange' for a student, and therefore, the appraisal judgments, which are opposite to the descriptions of the role of 'I am a student', 
are used in its description. In addition, the analysis of the content of appraisal judgments expressed in relation to the position 'They are not students' has revealed the expansion of the repertoire of the situations of the absence of the status of student in the individual: from 'hooligans', 'drug addicts', 'lazy', etc. in the responses of students of the first year to 'have already received a specialist diploma', 'teachers', 'have other plans for life', etc. in the responses of senior students.

4. In the process of the analysis of students' answers for questions 4 and 5 of the questionnaire, the influence of the professionalisation and professional training crisis on the evaluative judgments as for the various sides of a professional was identified. Students, as a rule, formulated from 3 to 5 questions for the imaginary professional. Thus, the first year students asked the imaginary professional the question about the correct choice of profession in $87.8 \%$ of cases, about the emotional experiences caused by the profession (75.7\%), about the general impression of it (51.5\%), etc. This is the evidence of the continuation of the process of professional self-determination and the development of the professional identity. Third-year students tend to be interested in specific technologies of professional activity (84.6\%), because during this period the intensive mastery of the necessary system of professional knowledge, professional culture and professional competences takes place [6].

The graduate students were interested in the searching of jobs and employment (54.8\%), the intricacies (secrets) of successful professional activity (87.1\%), the ways of making career (41.9\%), and the peculiarities of professional communication $(22.6 \%)$ etc. Such questions indicate the attempts to build professional life plans, a tendency to career planning and development of psychological readiness for future professional activity.

Analysing the respondents' performance of the fifth task of the questionnaire, we have revealed that students were unable to find answers for their questions. On the one hand, this indicates that students have lack of professional experience to answer, but the posed questions really worry them. At the same time, the inability to give detailed answers shows the problematic moments of the professional consciousness development as well as the formation of a future professional in higher educational institution. The identified problems should become the subject of psychological correction and development of students in

Table 2.

The frequency of categories recorded in the evaluative judgments of positions 'I am a student', 'We are students', 'They are not students' in the whole sample by the term of study (\%).

\begin{tabular}{|c|c|c|c|c|c|c|c|c|}
\hline \multirow[b]{2}{*}{ Categories } & \multicolumn{8}{|c|}{ The frequency of categories manifestation (\%) } \\
\hline & 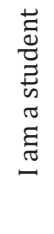 & 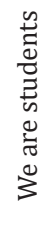 & 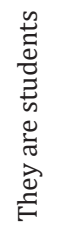 & 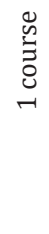 & 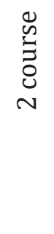 & 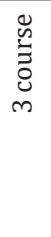 & 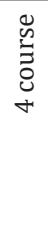 & 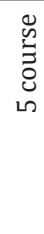 \\
\hline active life & 29 & 49 & 22 & 15 & 32 & 10 & 15 & 28 \\
\hline interesting job & 41 & 41 & 18 & 20 & 28 & 13 & 21 & 18 \\
\hline $\begin{array}{l}\text { the presence of good } \\
\text { and loyal friends }\end{array}$ & 24 & 69 & 7 & 46 & 14 & 9 & 13 & 18 \\
\hline social recognition & 45 & 37 & 18 & 31 & 16 & 14 & 27 & 12 \\
\hline knowledge & 33 & 25 & 42 & 17 & 46 & 27 & 8 & 2 \\
\hline responsibility & 72 & 8 & 20 & 44 & 2 & 8 & 15 & 31 \\
\hline self-control & 57 & 32 & 11 & 25 & 11 & 3 & 29 & 32 \\
\hline life wisdom & 42 & 17 & 41 & 21 & 17 & 8 & 50 & 4 \\
\hline material support & 17 & 25 & 58 & 17 & 33 & 0 & 17 & 33 \\
\hline entertainment & 44 & 21 & 35 & 10 & 0 & 48 & 15 & 27 \\
\hline cheerfulness & 32 & 44 & 24 & 20 & 0 & 28 & 4 & 48 \\
\hline discipline & 21 & 27 & 52 & 41 & 0 & 3 & 35 & 21 \\
\hline education & 38 & 34 & 28 & 60 & 15 & 0 & 4 & 21 \\
\hline
\end{tabular}


the process of study. In particular, 38.3\% of the respondents failed to give any answer to the formulated questions, and $60.6 \%$ of the respondents gave short, superficial answers to the questions (for example, 'Yes', 'I like', 'Wonderful profession', 'It is necessary to work a lot on myself', etc.). The number of $15.9 \%$ of respondents (mostly graduate students) managed to partially reveal the nature of the problems formulated in the questions.

5. In consideration of the problem of development and correction of professional consciousness, as well as of its connection with such attribute as value orientations, the analysis of representation of the cognitive component of social-role attitude in the system of evaluative judgments seems to be of a particular interest.

In the course of the system of evaluative judgments analysis of the system of evaluative judgments, which we attributed to the cognitive component of the social attitudes, 29 categories that reflect the system of students value orientations, as well as linguistic speech units, the elements of content that correspond to them, and units of quantification, were identified. Evaluative judgments reflecting the corresponding to them value orientations have different frequency of manifestation by the description of the various social-role attitude components ('I am a student', 'We are students', 'They are not students') by students of different courses and forms of study (full-time, part-time). As many as 8 categories (active life, life wisdom, interesting job, the presence of good and loyal friends, social recognition, knowledge, responsibility, self-control) have the highest frequency of manifestation among the 29 categories in the whole sample when answering all the questions from the questionnaire. Another five categories (material support, entertainment, cheerfulness, discipline, education) have a fairly high rate of manifestation, but they are missing in the 2nd or 3rd year students' responses (see Table 2.).

It should be noted that while formulating evaluative judgments from the position 'They are not students', the respondents used mainly negative evaluative judgments of a certain category.

The increase or decrease of the frequency of manifestations of categories, which are fixed in evaluative judgment of different positions 'I am a student', 'We are students', 'They are not students' are logical. We have found an increase in the frequency of manifestations of the analysis units by the categories of responsibility, social recognition, self-control, entertainment, education in the position 'I am a student'. The social attitude, accordingly, depicts the socially desirable role of a student, who studies and does not forget about recreation and entertainment, and, at the same time, bears responsibility for his own actions.

The system of evaluative judgments in the position 'We are students' as for the categories the presence of good and faithful friends, active life, cheerfulness, has the highest frequency manifestations. In the social attitude, the student life implies very intense contacts between students and teachers, the fullness of life and, as a result, sense of joy and happiness.

The position 'They are not students' has significant frequency manifestations in some categories (for example, discipline, material support, knowledge). However, these evaluative judgments are negative.

Statistical analysis. The researchers used the criterion of the Fisher's transformation $\varphi^{*}$ for the static processing of the data obtained and the determination of statistical significance in the dynamics of the frequency categories. It should be noted that the empirical values of the criterion were determined for the level of statistical significance $\mathrm{p} \leq$ 0.01 .

As for the category active life, the frequency of estimative judgments is observed among students of the 2nd year (part-time students, all the students work on a specialty) and 5th course (full-time students). The following statistically significant differences are established: 1st and 2nd courses ( $\left.\varphi^{*}=4.18\right)(\mathrm{p} \leq 0.01)$; 3rd and 2nd courses $\left(\varphi^{*}=2.584\right)(\mathrm{p} \leq 0.01)$; 4 th course and 2 nd course $\left(\varphi^{*}=2.328\right)(\mathrm{p} \leq 0.01) ; 1$ st and 5 th courses $\left(\varphi^{*}=4.281\right)$ $(\mathrm{p} \leq 0.01)$; 3rd and 5th course $\left(\varphi^{*}=2.737\right)(\mathrm{p} \leq 0.01)$; 4 th and 5th course $\left(\varphi^{*}=2.493\right)(p \leq 0.01)$. The found differences indicate that the growth of quantitative data is statistically significant. The 2nd year students who carry out professional activity, and graduate students who have completed their studies and determined their place of work, evaluate the role of the student from the point of view of professional activity and considerably more appreciate the opportunities provided by student life.

As for the category the presence of good and faithful friends, only among the first year students the high frequency of evaluative judgments is observed. The following statistically significant differences were found in this category: 1 st and 2 nd courses $\left(\varphi^{*}=2.613\right)$ ( $\left.p \leq 0.01\right)$; 1st and 3rd courses $\left(\varphi^{*}=2.807\right)(p \leq 0.01)$; 1st and 4th courses $\left(\varphi^{*}=2.488\right)(p \leq 0.01)$; 1 st and 5th courses $\left(\varphi^{*}=2.357\right)(\mathrm{p} \leq 0.01)$. The identified differences indicate that the change in quantitative data is statistically significant. These differences confirm the importance of the reducing of quantitative data for each year of study. From the position of senior students, a united students group does not play a decisive role in obtaining a profession.

High frequency rates in the category of knowledge are recorded among 2 nd year part-time students. The following statistically significant differences were established: 1 st and 2nd courses $\left(\varphi^{*}=3.631\right)$ ( $\left.\mathrm{p} \leq 0.01\right)$; 3rd and 2nd courses $\left(\varphi^{*}=2.728\right)(\mathrm{p} \leq 0.01) ; 4$ th and 2 nd course $\left(\varphi^{*}=5.045\right)$ $(\mathrm{p} \leq 0.01) ; 5$ th and 2 nd course $\left(\varphi^{*}=6.808\right)(\mathrm{p} \leq 0.01)$. The identified differences indicate that the change in quantitative data is statistically significant. These differences confirm 
the importance of obtaining knowledge, the formation of professional skills and skills of future professionals as well as evidence the awareness of the importance of this component in professional activity.

A similar situation is observed in the category of education, however, the highest frequency rates were found among first-year students. The following statistically significant differences were established: 1 st and 2 nd courses $\left(\varphi^{*}=4.707\right)(\mathrm{p} \leq 0.01) ; 1$ st and 4 th courses $\left(\varphi^{*}=6.525\right)$ $(\mathrm{p} \leq 0.01) ; 1$ st and 5 th courses $\left(\varphi^{*}=3.902\right)(\mathrm{p} \leq 0.01)$. The found differences indicate that the reducing of quantitative data is statistically significant. These differences confirm that, according to the attitude 'student - a person with a broad worldview, a circle of interests, erudite and inquisitive', the student's awareness of a wide range of issues is welcomed. The reduction of the frequency of the category in the evaluative judgments of senior students is to advantage of knowledge of the profession.

As for the category interesting job a decrease in the frequency of manifestation of evaluative judgments among the third year students is observed. The following statistically significant differences were established: 1 st and 3rd courses $\left(\varphi^{*}=0.458\right)(\mathrm{p} \leq 0.01) ; 2$ nd and 3rd courses $\left(\varphi^{*}=0.92\right)(p \leq 0.01) ; 4$ th and 3rd course $\left(\varphi^{*}=0.643\right)$ ( $\mathrm{p} \leq 0.01)$; 5th and 3rd courses $\left(\varphi^{*}=0.317\right)(\mathrm{p} \leq 0.01)$. The established differences indicate that the reduction of quantitative data is not statistically significant. Therefore, it can be stated that there is no confirmation of the established trend. This category does not have any significant part in the structure of social attitude.

As for the category of responsibility, an increase of the frequency of manifestations of evaluative judgments in 1 st and 5th year students (full-time) is observed. The following statistically significant differences are established: 1 st course and 2 nd courses $\left(\varphi^{*}=3.423\right)(\mathrm{p} \leq 0,01) ; 1$ st and 3rd courses $\left(\varphi^{*}=2.807\right)(\mathrm{p} \leq 0.01)$; 1 st and 4 th courses $\left(\varphi^{*}=2.488\right)(p \leq 0.01)$. The established differences indicate that the growth of quantitative data is statistically significant. Statistically significant differences are established: $2 \mathrm{nd}$ and 5 th courses $\left(\varphi^{*}=1.231\right)$ ( $\left.\mathrm{p} \leq 0.01\right)$; 3rd and 5th course $\left(\varphi^{*}=0.736\right)(p \leq 0.01) ; 4$ th and 5 th courses $\left(\varphi^{*}=1.01\right)$ ( $\mathrm{p} \leq 0.01)$. They prove that the growth of quantitative data is not statistically significant. The first year students, talk about responsibility as the main value of students life for the freshmen, It becomes important for them due to the adaptation processes that take place during the transition to educational and professional activity. Senior students pay little attention to this category.

High frequency data of the category discipline are observed among students of 1st and 4th courses (full-time form of studies). The following statistically significant differences are established: 1 st and 3 rd courses $\left(\varphi^{*}=2.428\right)$ $(\mathrm{p} \leq 0.01) ; 1$ st and 5 th courses $\left(\varphi^{*}=1.381\right)(\mathrm{p} \leq 0.01) ; 4$ th and 5th course $\left(\varphi^{*}=1.088\right)(\mathrm{p} \leq 0.01)$; 3rd and 4 th courses $\left(\varphi^{*}=2.025\right)(\mathrm{p} \leq 0.01)$, which indicate that the change of quantitative data is statistically significant only on the sample of students of 1 st and 3rd courses. For other pairs, the differences are statistically insignificant. Only the first year students consider discipline an important feature of the student.

Discussion. The separation of three-component structure of social attitude according to the basic statements of foreign psychology $[7,8]$ allows to observe the dynamics of its structural changes. Social attitude, as a system of evaluative judgments, contains an emotional assessment of an object, awareness and consecutive behaviour, that is, three components: affective, cognitive, and behavioural [9]. A. Harrison, arguing that convictions reflect the basic values of a person and generate judgments that reveal the meaning of values, separates the same components of a social attitude, and calls them beliefs, emotions and behaviour [10]. By the way, the object of the social attitude can be separate objects of activity, as well as social situations and other social objects. The social attitude, as an estimative reaction (estimated attitude), can be expressed both in positive and in negative feelings and intentions [8], that is, to be ambivalent [9].

Personally-professional formation of the future specialist is impossible without acceptance and development of a professional role, since, as noted by I. D. Bekh, 'personal is appearing through the role in the individual» [11, p.187]. V. M. Miasishchev argued, that 'the concept of consciousness includes both knowledge, awareness of the object of the external world, and the relation of man to conscious objects' $[12$, p.16]. The content and dynamic characteristics of professional consciousness are manifested in the system of motives, personal meanings and values (N. I. Husliakova) [2]. H. M. Andreieva includes in the subjective attitudes experience, assessments and attitudes [13]. Attitude as well as meanings and attitudes precede the implementation of behaviour, create conditions for the predicting of the professional's behaviour. This is proved by the explorations in the field of professional consciousness in psychological science, that is considered in the context of the essence of the process of professional formation and development of the professional's personality (N. F. Shevchenko) [14].

Changing of the social-role attitudes as an attribute of professional consciousness for the formation of a professional's personality is possible in the process of study, as, according to O. H. Asmolov and N. L. Kolomynskyi, personality attitudes are re-educated and retrained. The greatest reserves in this sense, according to N. L. Kolomynskyi, have active forms and methods of teaching of psychology [5]. 
Moreover, according to the practice of the active studying technologies usage, they, due to N. O. Yevdokymova and Yu. M. Shvalba, make it possible to create a special educational space, where not only the personal experience of the student is actualised, but also his/her own limits are realised and emotionally experienced, and the collective searching of ways to act in the situation of uncertainty, algorithmisation and assignment by each student [15]. That is why it seems expedient to us to introduce into practice of the organisation of educational process, the educational psychological training, which allows us to move to a qualitatively new level of understanding of ourselves and others, of professional activity and ensures the formation of social-role attitudes, in particular, and professional consciousness in general.

The studies have developed the psychological training program designed for 24 hours, which contains 6 lessons, each for 4 hours. During the training lessons students were offered the system of exercises for the development of professional consciousness and correction of social-role attitudes. Each of them forced the students to analyse the life prospects and plans, to identify the potential of the planned implementation, to correlate their capabilities with aspirations, dreams with the ability to realise them, that is, meaningfully, all the exercises required reflexive actions. In addition to these reflexive actions, the reflection exercise aimed to help students understanding the changes in attitudes, mood, plans for the future, etc. which they had noticed was conducted after each lesson. Exercises included in the training lessons can be classified in terms of the content and purpose of personal changes that they pursue: awareness of the attitude to psychology (pedagogy) as a sphere of the professional activity, awareness of the features of the image of the profession and the image of the professional, the reflection of life and professional values and goals, formation of the ability to plan, analysis of the professional role and the professional position.

\section{Conclusion}

The research revealed the content peculiarities of students' social-role attitudes at different stages of vocational training and in different forms of study at higher educational institution. Social attitudes regarding the role of student and the role of professional have a three-component structure (cognitive, emotional and behavioural), differing in degree of awareness and completeness, are ambivalent, which increases their resilience to changes.

The results of the research show that the social-role attitudes undergo changes as a result of targeted influences in the process of professional training of future specialists at higher educational institution. Students of all courses and forms of education were least inclined to express their own probable behaviour as for the objects/situations proposed for the assessment. Verbalization of emotions in the situation of the survey required high-class subjects and situations that are beyond the educational activity and role of the student.

The system of evaluative judgments, that form the cognitive component of the social-role system, reflects the corresponding system of value orientations. The eight categories (active life, life wisdom, interesting work, the presence of good and faithful friends, social recognition, knowledge, responsibility, self-control) have the highest frequency of manifestation in the whole sample. This determines the successful professionalization of students.

Therefore, the special study of the professional consciousness components, defining the social-role attitudes features is a promising area of scientific researches, which will contribute to the development of effective training technologies of the professionals. It will significantly change the psychological and pedagogical conditions of the professional and personal formation of a specialist with higher education.

\section{Conflict of interest}

The authors have declared no conflict of interest.

\section{References}

1. Meshko H. M. (ed.) V. V. Kravets: Preparation of future teachers to the preservation and strengthening of the professional health: [monograph]. Ternopil, TNPU by V. Hnatyuk, 2012: 468.

2. Guslyakova N. I.: Psychological mechanisms of formation of the professional consciousness of the future teacher: author's abstract. dis. of PhD, Samara, 2010: 40.

3. Yadov V. A.: On the dispositional regulation of social behavior of a person. Methodological problems of social psychology: ed. E.V. Shorokhova. Moscow, 1975.

4. Akopov H. V.: Diagnostics of the professional consciousness. Psychology in high school, nr 4, 2004: 3 -38.

5. Kolomynskyi N. L.: Psychology of management in education (sociopsychological aspect: monograph. Kyiv, MAUP, 2000: 286.

6. Panok V., Titanenko T., Chepeleva N., etc.: Fundamentals of Professional Psychology, ed V. Panok, Kyiv, Lybid, 2001: 536.

7. Petty R. E., Wegener D. T.: Attitude change: Multiple roles for persuasion variables. Gilbert D.T., Fiske S.T., Eindzey G. The Handbook of Social Psychology, New York, McGraw-Hill, 1998, Vol. 1:323-390.

8. Tesser A., Martin E., Mendolia M.: The impact of Thought on the attitude of extremity and attitude-behavior consistency. Petty R., Krosnick Attitude strength: Antecedents and consequences, Ohio State University series on attitudes and persuasion, 1995, Vol. 4. Mahwah, NJ: Lawrence Erlbaum Associates: 73-92.

9. Zelinskaya T. M.: Ambivalent person. Theory, diagnostics and psychocorrection. Kyiv, Karavela, 2010:256.

10. Harrison A.A.: Individuals and groups . Monterey, Calif, Brooks / Cale, 1976.

11. Bekh I. D.: Education of the person: In 2 books. Book 1: Personalityoriented approach: theoretical and technological principles: teaching method. Edition. Kyiv, Lybid, 2003. 
12. Miasyshchev V. N.: Psychology of relationships, Moscow, 1995.

13. Andreieva H. M.: Actual problems of social psychology. [MSU by. M. V. Lomonosov Moscow State University Faculty of Advanced Studies. Faculty of Psychology]. Moscow,Publishing House of Moscow State University, 1988.

14. Shevchenko N. F.: Professional Consciousness of a Psychologist: Methodological and Applied Aspect. Problems of Contemporary Psychology: Science works collection Institute of Psychology named by H. S Kostiuk NAPS of Ukraine; The State Higher Educational Establishment «Zaporizhzhia National University», nr 1, 2012: 16-23.

15. Yevdokymova N. O., Shvalb Yu. L.: Educational training as a technology for training of a specialist in the university. Scientific bulletin of Mykolaiv state university named after V. O. Sukhomlynskyi. Series: Psychological sciences: a collection of scientific works. Mykolaiv, V. O. Sukhomlynskyi National University of History, 2011. Tom 2. Issue. 7: 121-217.Correspondence address

\section{Corresponding adress}

Olha Savytska

Kamianets-Podilskyi National Ivan Ohiienko University olganeu717@gmail.com

Otrzymano: 10.01 .2018

Zrecenzowano:14.01.2018

Przyjęto do druku: 06.03.2018 